\title{
PREVALENCE OF ATLANTO-AXIAL INSTABILITY AND ITS ASSOCIATION WITH CLINICAL SIGNS IN CHILDREN WITH DOWN SYNDROME
}

\author{
Érica Cesário Defilipo', Priscila Cristian do Amaral2 ${ }^{2}$ Natália Trindade de Souza², \\ Carla Trevisan Martins Ribeiro ${ }^{3}$, Paula Silva de Carvalho Chagas ${ }^{4}$, \\ Flávio Augusto Teixeira Ronzani ${ }^{5}$
}

\begin{abstract}
Introduction: A change in the atlanto-axial alignment in children with Down syndrome may be associated with pain, neurological disorders, high spinal cord compression and sudden death. Objective: To determine the prevalence of atlanto-axial instability in children with Down syndrome and its association with the presence of signs and symptoms of atlanto-axial instability. Methods: A cross-sectional study evaluated 21 children with Down syndrome aged between 3 and 5 years. Children who had undergone cervical spine surgery or who had diseases not associated with this syndrome were excluded. Sex, age, ethnicity of the child and the presence of signs suggestive of atlanto-axial instability, as reported by caregivers, such as neck pain, difficulty walking, weakness in the lower limbs, fatigue, difficulty with balance, urinary and fecal incontinence and projectile vomiting were studied. Children underwent a cervical spine $X$-ray in the lateral view in three positions: neutral, flexion and extension. When the atlasodontoid distance was equal to or greater than $4.5 \mathrm{~mm}$, atlanto-axial instability was diagnosed. Results: The prevalence of atlanto-axial instability in the studied population was $9.5 \%$. There was no significant association revealed in the chi-square test between the signs suggestive of atlanto-axial instability and the presence of atlanto-axial instability $(p>0.05)$. Conclusions: Atlanto-axial instability is possibly not associated with its suggestive signs.
\end{abstract}

DOI: http://dx.doi.org/10.7322/jhgd.102996

Key words: Down Syndrome, Joint Instability, Atlanto-axial Joint, X-rays, Prevalence.

\section{INTRODUCTION}

Down syndrome is characterized as a genetic condition that causes mental retardation and dysmorphic changes such as superior eyelid slope, single palmar crease, small mouth, small ears, protruding tongue and greater space between the first and the second toes ${ }^{1}$.

Other Down syndrome features are neuromuscular and osteoarticular disorders, highlighting muscle hypotonia, muscle weakness, ligament laxity and joint hypermobility ${ }^{1}$. The ligamentous laxity and generalized hypotonia are characteristics that contribute to the change of alignment in the atlantoaxial segment in children with Down syndrome ${ }^{1,2}$.

The atlanto-axial instability is defined as a greater mobility of the first cervical vertebra (atlas) on the second vertebra (axis) ${ }^{3}$. The relationship between Down syndrome and this condition was described by Spitzer in 19614,5. In most cases atlanto-axial instability is asymptomatic ${ }^{4}$ and only $1 \%$ to $2 \%$ of individuals with this condition have signs and symptoms of neurological impairment secondary to spinal cord compression, such as fatigue, difficulty walking, gait alteration, neck pain, decreased neck mobility, torticollis, sensory deficits, spasticity and others.

The change in alignment of the atlanto-axial segment can be associated with pain, neurological disorders, high spinal cord compression and, in some cases, can cause sudden death. Although in most individuals with Down syndrome, atlanto-axial instability is treated conservatively or periodically followed up, in some situations in which there are neurological changes, surgery is needed ${ }^{4}$.

It is imperative that health care professionals be aware about the presence of this condition, since physical activity involving cervical flexion may cause subluxation or luxation of the vertebrae and may result in spinal cord compression ${ }^{4,5}$.

Thus, children with Down syndrome and with evidence of atlanto-axial instability must be routinely submitted to radiographic survey of the cervical spine before practicing sports ${ }^{4,5}$. Also, an educational program for health care professionals is needed, especially for physiotherapists, to promote awareness of the appropriate therapy, in order to avoid handling or postural placements

\footnotetext{
1 Departamento de Fisioterapia, Universidade Federal de Juiz de Fora (UFJF) - Campus Governador Valadares - Governador Valadares (MG), Brasil.

2 Faculdade de Fisioterapia, UFJF - Juiz de Fora (MG), Brasil.

3 Instituto Nacional da Saúde da Mulher, da Criança e do Adolescente, Fernandes Figueiras (IFF/FIOCRUZ) - Rio de Janeiro (RJ), Brasil.

4 Departamento de Fisioterapia do Idoso, do Adulto e Materno-infantil, Faculdade de Fisioterapia, UFJF - Juiz de Fora (MG), Brasil.

5 Departamento de Clínica Médica da Faculdade de Medicina, UFJF - Juiz de Fora (MG), Brasil.

Corresponding author: Érica Cesário Defilipo. E-mail: ericadefilipo@yahoo.com.br
} 
that can provide some risk to the child during treatment ${ }^{6}$.

According to the Pediatric Society of Rio de Janeiro, a child with Down syndrome needs to be assisted from the first months of life by pediatricians who should aim for early diagnosis and appropriate management? ${ }^{7}$.

During the first months of life, pediatricians need to educate caregivers about the potential secondary conditions associated with the syndrome, such as cardiopathy, delayed motor development, neurological deficit, auditory and visual deficits ${ }^{2}$, and refer to other professionals. In addition, pediatricians should adopt radiological investigation of the cervical spine in lateral view as a routine investigation to evaluate the atlanto-axial joint of patients with Down syndrome?

An emphasis on the diagnosis of atlanto-axial instability in children with Down syndrome reinforces their right to receive adequate rehabilitation $^{8}$ and reaffirms the principles of the Public Health System (SUS) in the context of child health care recovery ${ }^{9}$. An identification of atlantoaxial instability enables a referral to specialized services and individualized treatment ${ }^{5}$.

According to Costa and Herrero ${ }^{10}$, a child with Down syndrome tends to receive the same type of therapy as a child with delayed motor development, as they have a similar clinical presentation. These authors highlight the importance of choosing specific therapeutic approaches, as well as optimizing individualized strategies for this population.

Thus, the objective of this study is to estimate the prevalence of atlanto-axial instability in children with Down syndrome and evaluate the association between this condition and its specific signs and symptoms, such as neck pain, difficulty in walking, weakness in the lower limbs, fatigue, balance difficulties, urinary and fecal incontinence and projectile vomiting.

\section{METHODS}

This is a descriptive cross-sectional study, which included the participation of children with a diagnosis of Down syndrome, aged between three and five years. The restriction of participant age follows the recommendation of the American Academy of Pediatrics, which states the need for radiological evaluation in this age group in patients with Down syndrome ${ }^{\text {. }}$

Children who had undergone cervical surgery and who had diseases not associated with the syndrome were excluded. Initially, the researchers contacted the directors of both public and private institutions offering treatment to children with Down syndrome in the city of Juiz de Fora in order to inform them about the scope of this research, and they provided data on the Down syndrome children registered with them.

Twenty-two families who were being followed by these institutions were invited to participate through up to three telephone contact attempts. All the registered responsible adults agreed to the child's participation, and only one family listed on the database did not participate due to the death of the child. In this way, the guardians were invited by telephone to participate in this study and, accepting, a time for the clinical and radiological evaluation was scheduled.

On the assessment day, caregivers first received an explanation about the study procedures and risks associated with X-ray, as well as its importance for early detection of changes in the region of the atlanto-axial joint and the implications for the child's future health and wellbeing.

This research was approved by the local Ethical Committee (Number 216/2011) and the guardians signed an Informed Consent.

The child's data (gender, age and ethnicity), as well as the presence of signs suggestive of atlanto-axial instability, such as neck pain, walking difficulty, weakness in the lower limbs, fatigue, difficulty with balance, fecal and urinary incontinence and projectile vomiting, were obtained through an interview with the caregiver and recorded on a form by one of the researchers. This researcher did not have access to data on the possible diagnosis of atlanto-axial instability from previous radiographic evaluation, nor did the researcher know the results of the radiographic examination in this study.

Subsequently, children underwent cervical spine $X$-ray in three positions: neutral, flexion and extension, according to the method proposed by the Americas Paralympic Committee ${ }^{11}$ and the American Academy of Pediatrics ${ }^{7}$ and in accordance with all protection standards cited by the Guidelines Manual on Best Practice in the X-Ray Imaging of Children ${ }^{12}$.

The radiographs were evaluated by a radiologist or doctor, who had previously participated in a reliability test with and between examiners (with the other radiologist in the service) to calculate the rate of agreement, obtaining reliability superior to 0.80 . In the three radiographic positions (neutral, flexion and extension) the analysis was made from a perpendicular line from the lower end of the anterior arch of the first cervical vertebra (atlas) to the front edge of the dens (odontoid process) ${ }^{5}$.

Although the literature is not consistent regarding the value adopted for the atlas-odontoid distance to be considered normal, for this study the value for diagnosing atlanto-axial instability was equal to or greater than 4.5 millimeters, as proposed by the Americas Paralympic Committee and the American Academy of Pediatrics ${ }^{11}$. This review and analysis was performed blind by a radiologist, who did not know the possible clinical signs of atlantoaxial instability presented by the children.

Data were analyzed using SPSS $14.0^{\circledR}$. Firstly, the data were verified by the Shapiro-Wilk test; the data did not meet the normality criteria. So, the application of nonparametric techniques was chosen to test the significance of associations.

Descriptive analysis was performed including age, sex and ethnicity of the children and the presence of signs suggestive of atlantoaxial instability. An estimate of atlanto-axial 
instability prevalence was made through the ratio between the number of cases in the sample and the number of children assessed. Finally, to assess the association between the signs suggestive of atlanto-axial instability with the presence of this condition, a chi-square test $\mathrm{c}^{2}$ ) was used. For all statistical analyses the significance level was determined as $\alpha=0.05$.

\section{RESULTS}

The study sample comprised 21 children with Down syndrome, being $52.4 \%$ male, mean age 3.95 years $(S D=0.86)$ with predominance of white ethnicity $(81.0 \%)$.

Only two children had atlanto-axial instability (atlas-odontoid distance equal to or greater than $4.5 \mathrm{~mm}$ ), indicating a prevalence of
$9.5 \%$ of this condition in the study sample. In addition, there was one child with underdevelopment of the odontoid process and one with spondylolisthesis C3-C4.

Some children showed signs suggestive of atlanto-axial instability, as reported by caregivers, the most common being fecal and urinary incontinence $(61.9 \%)$, difficulty walking (23.8\%), balance problems (14.3\%) and fatigue $(14.3 \%)$ followed by neck pain $(4.8 \%)$ and weakness in the lower limbs (4.8\%). Other signs in the literature, such as epilepsy, limited head movement and dizziness, were not found in this sample.

There was no significant association verified through the use of the chisquare test $\chi^{2}$ ), between the signs and symptoms suggestive of atlanto-axial instability presented by the children and the presence of the condition, as can be seen in Table 1.

Table 1: Association between atlanto-axial instability and presence of suggestive signs and symptoms

\begin{tabular}{|c|c|c|c|c|}
\hline \multirow{2}{*}{$\begin{array}{l}\text { Signs and symptoms suggestive of } \\
\text { Atlanto-axial Instability }\end{array}$} & \multicolumn{2}{|c|}{ Classification } & \multirow{2}{*}{$\chi^{2}$} & \multirow{2}{*}{ p-value } \\
\hline & $<4.5$ & $\geq 4.5$ & & \\
\hline \multicolumn{5}{|l|}{ Neck Pain } \\
\hline Yes & 1 & 2 & 0.11 & 1.00 \\
\hline No & 18 & 0 & & \\
\hline \multicolumn{5}{|l|}{ Difficulty walking } \\
\hline Yes & 4 & 1 & 0.84 & 0.43 \\
\hline No & 15 & 1 & & \\
\hline \multicolumn{5}{|l|}{ Weakness of lower limbs } \\
\hline Yes & 1 & 0 & 0.11 & 1.00 \\
\hline No & 18 & 2 & & \\
\hline \multicolumn{5}{|l|}{ Tiredness } \\
\hline Yes & 3 & 0 & 0.37 & 1.00 \\
\hline No & 16 & 2 & & \\
\hline \multicolumn{5}{|l|}{ Difficulty with balance } \\
\hline Yes & 3 & 0 & 0.37 & 1.00 \\
\hline No & 16 & 2 & & \\
\hline \multicolumn{5}{|l|}{ Urinary and Fecal Incontinence } \\
\hline Yes & 13 & 0 & 3.59 & 0.13 \\
\hline No & 6 & 2 & & \\
\hline \multicolumn{5}{|l|}{ Projectile Vomiting } \\
\hline Yes & 5 & 0 & 0.69 & 1.00 \\
\hline No & 14 & 2 & & \\
\hline
\end{tabular}

Legend: $p=$ level of statistical significance; $\chi^{2}=$ test values chi-square; Rate $<4.5$ mm indicating no atlanto-axial instability. Rating $\geq 4.5 \mathrm{~mm}$ indicative of the presence of atlanto-axial instability.

\section{DISCUSSION}

In order to determine the prevalence of atlanto-axial instability in children with Down syndrome and evaluate the association between this condition and its specific signs and symptoms, a prevalence of $9.5 \%$ was found, however the cases were all asymptomatic, showing no association with clinical findings suggestive of this condition.

Regarding the presence of atlanto-axial instability in children with Down syndrome, the literature is vast and controversial regarding both the prevalence of this condition and the presence of clinical signs and symptoms.

According to Barros Filho et al. ${ }^{4}$ and Boechat et al. ${ }^{5}$, atlanto-axial instability affects about $10 \%$ to $30 \%$ of individuals with Down syndrome, but is symptomatic in only $1 \%$ to $2 \%$. Merrick et al. ${ }^{13}$, in a study of 404 participants with Down syndrome between 0 and 19 years old, showed that 59 participants (14.6\%) had atlanto-axial instability, and in 53 participants the condition was asymptomatic.

Casas et al. ${ }^{14}$ evaluated 37 patients with Down syndrome aged between 5 and 47 years, 3 of them had atlanto-axial instability, which was asymptomatic in all cases. Szpak et al. ${ }^{15}$ investigated the prevalence of atlanto-axial instability in subjects 2.5 to 15 years old, verifying that none of the 30 participants showed atlasodontoid distance equal to or greater than 4.5 millimeters.

Some of the signs suggestive of atlantoaxial instability, such as balance difficulties, urinary and fecal incontinence, weakness in the lower limbs and walking difficulties seem to be peculiar to children with Down syndrome in the studied age group (3-5 years), making it difficult to 
discriminate such features as the specific symptoms of atlanto-axial instability. This result corroborates the study of Szpak et al. ${ }^{15}$ that although they found no cases of atlanto-axial instability in their participants, they found some suggestive signs such as cervical/stiff neck discomfort $(6.6 \%)$, sphincter control problems $(16.6 \%)$ and complaining of pain in the upper and lower spine $(3.3 \%)$.

While members of the Medical Division of the Special Olympics have determined since 1983 that every athlete with Down syndrome should be evaluated by cervical spine radiography before the sport $^{11}$, some literature data conflicts with this requirement.

Casas et al. ${ }^{12}$ encourage individuals with Down syndrome to play sports, even those with atlanto-axial instability, and judge the radiological screening recommended by the Medical Division of the Special Olympics to be unnecessary. Szpak et al. ${ }^{15}$ corroborate these authors, stressing the absence of scientific evidence to prove the need for radiographic follow-up in these individuals.

However, considerable scientific support from institutions such as the American Academy of Pediatrics, the Genetics Committee of the American Academy of Pediatrics and the Americas Paralympic Committee encourage this radiographic investigation and judge it as an essential preventive measure for this population ${ }^{11}$.

So, it seems that radiographic follow-up at an early age is necessary for these children, such as in the age range covered in this study, considering that clinical symptoms may not be associated to the clinical changes suggestive of atlanto-axial instability, and sports activities can become dangerous in the absence of this information.

According to Ribeiro and $\mathrm{Sa}^{6}$, verifying the presence of atlanto-axial instability in children with Down syndrome is important so that appropriate practices are established in their rehabilitation avoiding exaggerated flexion positions, extension, rotation and forced turning of the head.

Another factor that motivates research on atlanto-axial instability in children with Down syndrome is the practice of sports activities, as the choice of sport will depend on the child's physical condition and having been checked for this condition. Considering the high rates of obesity in this population ${ }^{16,17}$, encouraging physical activity and combating a sedentary lifestyle are fundamental and should be safely emphasized based on atlanto-axial instability investigation.

Studies on Down syndrome restricting the age to between 3 and 5 years, as recommended by the American Academy of Pediatrics ${ }^{18}$, were not

\section{REFERENCES}

1. Schwartzman, SJ. Síndrome de Down. São Paulo: Editora Mackenzie; 2000; p.16-31.

2. Moreira LMA, El-Hani, CN; Gusmão, FAF Gusmão. Down syndrome and its pathogenesis: considerations about genetic determinism. Rev Bras Psiquiatr. São Paulo: 2000; 22(2):96-99. found in the literature. This restriction allowed atlanto-axial instability to be investigated early while excluding possible failures; under 3 years old, the characteristics of atlas and axis ossification could cause misinterpretation of the atlanto-axial distance and odontoid aspect, which can lead in some cases to the need to repeat the review and, consequently, expose the child to more X-rays ${ }^{5}$. Note that the results of this study are specific to this population of children with Down syndrome covering the age group 3 to 5 years and cannot be generalized to the older population.

Some peculiarities of this research make it difficult to compare the results with those of similar studies $^{13-15}$, for example, the selected age of the sample. In addition, only two children were found to have atlanto-axial instability and they did not present with clinical symptoms, making analysis difficult. However, the prevalence of this condition is similar to that described in the literature.

The use of a cross-sectional study design is highlighted, allowing no inferences about possible future outcomes in appearance of signs and symptoms as well as the emergence of possible changes in the cervical spine. A possible limitation is the fact that signs suggestive of atlanto-axial instability were reported by caregivers, which brings the possibility of memory bias to the study and, therefore, the results should be interpreted with caution.

The results presented indicate important issues for clinical practice regarding the presence of atlanto-axial instability in children with Down syndrome, which may guide further studies that perform routine radiography and evaluate possible changes during the development of these children. This justifies the need for evaluation and monitoring by pediatricians of these children from the beginning of their development, and the importance of holding referrals with specialized professionals for these children to receive adequate multidisciplinary treatment to ensure comprehensive health care.

In conclusion, the prevalence of atlantoaxial instability in the study population was $9.5 \%$, however, the cases were asymptomatic, and there was no association between atlanto-axial instability and the signs and symptoms of this condition in the cervical spine.

\section{AKNOWLEDGEMENTS}

We thank the parents and children in this study, the professionals who established contact with the families, and also the Radiology Service of the University Hospital (UFJF) for performing the $\mathrm{X}$-rays.

DOI: http://dx.doi.org/10.1590/S151644462000000200011

3. Nahas MV, Rosário AV, Nahas AB, Luza GR. Instabilidade atlanto-axial em crianças com Síndrome de Down na Grande Florianópolis: um estudo piloto. ACM Arq Catarin Med. 1991; 20(4):149-154. 
4. Barros Filho TE, Oliveira RP, Rodrigues NR, Galvão PE, Souza MP. Instabilidade atlantoaxial na Síndrome de Down. Relato de 10 casos tratados cirurgicamente. Rev Bras Ortop. 1998; 33(2): 91-94.

5. Boechat MCB, Silva KS, Llerena Junior JC. Instabilidade atlanto-axial na síndrome de Down: o que o radiologista precisa conhecer. Rev Imagem. São Paulo: 2006; 28(3): 171-179.

6. Ribeiro CTM, Sá MRC. Intervenção fisioterapêutica na Síndrome de Down. In: Associação Brasileira de Fisioterapia Neurofuncional. Garcia CSNB, Facchinetti LD, org. Programa de Atualização em Fisioterapia Neurofuncional: Ciclo 1. (Sistema de Educação em Saúde Continuada a Distância, v.1); Porto Alegre: Artmed; 2013; p.11-46.

7. Sociedade de Pediatria do Estado do Rio de Janeiro (SOPERJ). Síndrome de Down. [cited 2011 July 03] Available from: <http:// w w w. soperj.org.br/n socio/ textos_detalhe.asp $>$.

8. Brasil. Ministério da Saúde. Secretaria de Atenção à Saúde. Departamento de Ações Programáticas Estratégicas. Manual de legislação em saúde da pessoa com deficiência. 2. ed. Brasília: Ministério da Saúde; 2006; p.346. [cited 2012 July 07] Available from: http://bvsms.saude.gov.br/bvs/publicacoes/ legislacao_deficiencia.pdf.

9. Sales MLH, Ponnet L, Campos CEA, Demarzo MMP, Miranda CT. Quality of child health care in the Family Health Strategy. J Hum Growth Dev. 2013; 23(2): 151-156.

10. Costa A, Herrero D. Perspectives on the use of mouse models of down syndrome in translational research involving visual and motor functions. J Hum Growth Dev. 2014; 24(2):123-125.

11. American Academy of Pediatrics Committee on Sports Medicine. Atlantoaxial instability in Down syndrome. Pediatrics. 1984; 74(1): 152-54.
12. Cook JV, Pettett A, Shah K, Pablot S, Kyriou J, Fitzgerald M. Melhor prática em radiologia pediátrica: um manual para todos os serviços de radiologia. Rio de Janeiro: Editora Fiocruz; 2006; p.1001.

13. Merrik MDJ, Ezra E, Josef $B$, Hendel D, Steinberg DM, Wientroub S. Musculoskeletal problems in Down syndrome european pediatric orthopaedic society survey: the Israeli sample. J Pediatr Orthop B. Philadelphia: 2000; 9(3):185-92.

14. Casas DC, Andújar ALF, Marioto D, Rau LE, Pierite J, Schleder JC. Atlantoaxial instability in patients with Down's syndrome - its relation with sports activities and the prognosis based on radiological evaluation. Coluna/Columna. Santa Catarina: $2006 ;$ 5(1):43-45.

15. Szpak AM, Carvalho B, Cavichiolo JB, Mocellin M, Pereira R, Rezende RK. Há necessidade de solicitar de rotina radiografia da coluna cervical para pacientes portadores de síndrome de Down antes de se realizar cirurgia otorrinolaringológica? Arq Int Otorrinolaringol. São Paulo: 2011; 15(1):16-20. http:// d x . d o i . org/10.1590/S180948722011000100002

16. Ribeiro CTM. Estudo da atenção fisioterapêutica para crianças portadoras de Síndrome de Down no Município do Rio de Janeiro. Tese (Doutorado) - Universidade Federal do Rio de Janeiro. Rio de Janeiro: 2010.

17. Bertapelli F, Gorla JI, Silva FF, Costa LT. Prevalence of obesity and the body fat topography in children and teenagers with down syndrome. J Hum Growth Dev. 2013; 23(1): 65-70.

18. American Academy of Pediatrics. Committee on Genetics. American Academy of Pediatrics: Health supervision for children with Down syndrome. Pediatrics. 2001;107(2):442-49.

\section{Resumo}

Introdução: A alteração no alinhamento atlantoaxial em crianças com síndrome de Down pode estar associada à dor, transtornos neurológicos, compressão medular alta e até à morte súbita. Objetivo: Determinar a prevalência de instabilidade atlantoaxial em crianças com síndrome de Down e verificar a associação entre a instabilidade atlantoaxial e a presença de sinais e sintomas desta alteração. Método: Estudo transversal que avaliou 21 crianças com síndrome de Down com idade entre 3 e 5 anos. Não foram incluídas crianças que realizaram cirurgia cervical e com patologias não associadas à síndrome. Foram investigados sexo, idade e raça da criança e a presença de sinais sugestivos de instabilidade atlantoaxial segundo relato dos cuidadores, como dor no pescoço, dificuldade de andar, fraqueza em membros inferiores, cansaço, dificuldade de equilíbrio, incontinência fecal e urinária e vômito em jato. As crianças foram submetidas à radiografia da coluna cervical em perfil em três posições: neutro, flexão e extensão, sendo considerada instabilidade atlantoaxial quando a distância atlas-odontoide era igual ou maior que 4,5 milímetros. Resultados: A prevalência de instabilidade atlantoaxial na população estudada foi de 9,5\%. Não foi verificada, pelo teste Qui-quadrado, associação estatisticamente significativa entre os sinais sugestivos e a presença de instabilidade atlantoaxial ( $p$-valor $>0,05)$. Conclusão: A instabilidade atlantoaxial possivelmente não tem associação com os seus sinais sugestivos.

Palavras-chave: Síndrome de Down, Instabilidade Articular, Articulação Atlantoaxial, Raios X, Prevalência. 